\title{
Penjadwalan Produksi Garment Menggunakan Algoritma Heuristic Pour
}

\author{
Rizal Rachman \\ STMIK Nusa Mandiri Jakarta \\ e-mail: rizalkhaizuran@gmail.com
}

\begin{abstract}
Abstrak
Penjadwalan merupakan suatu kegiatan pengalokasian sumber daya yang terbatas untuk mengerjakan sejumlah pekerjaan. Proses penjadwalan timbul jika terdapat keterbatasan sumber daya yang dimiliki, karena pada saat ini perusahaan menerapkan sistem penjadwalan manual dimana dengan penjadwalan tersebut masih terdapat beberapa produk yang terlewati sehingga menyebabkan keterlambatan dalam proses produksi, aturan ini sering tidak menguntungkan bagi order yang membutuhkan waktu proses pendek karena apabila order itu berada dibelakang antrian maka harus menunggu lama sebelum diproses dan menyebabkan waktu penyelesaian seluruh order menjadi panjang, sehingga diperlukan adanya pengaturan sumber-sumber daya yang ada secara efisien. Adapun dasar perhitungan Penjadwalan dengan menggunakan algoritma Heuristic Pour. Tahapan-tahapan penelitian terdiri dari pengumpulan data, perhitungan waktu standar, perhitungan total waktu proses berdasarkan job, penjadwalan dengan metode awal perusahaan, penjadwalan dengan metode Heuristik Pour. Berdasarkan hasil penjadwalan menggunakan Heuristik Pour diperoleh penghematan dibanding dengan metode perusahaan saat ini, sehingga dapat digunakan sebagai alternatif metode dalam melakukan penjadwalan pengerjaan proses produksi di perusahaan Garment tersebut.
\end{abstract}

Kata kunci: Penjadwalan Produksi, Algoritma, Heuristic Pour.

\begin{abstract}
Scheduling is a limited resource allocation activity to do a number of jobs. The scheduling process arises if there are limited resources available, because at this time the company implement a manual scheduling system where the scheduling is still there are some products passed so as to cause delays in the production process, this rule is often not profitable for orders that require short processing time because if the order is behind the queue then it must wait a long time before it is processed and cause the completion time of all orders to be long, so it is necessary to regulate the existing resources efficiently. The basic calculation of Scheduling using Heuristic Pour algorithm. The research stages consist of data collection, standard time calculation, total time calculation based on job, scheduling with company start method, scheduling with Pour Heuristic method. Based on the results of scheduling using Pour Heuristik obtained savings compared with the current company method, so it can be used as an alternative method in scheduling the process of production process in Garment company.
\end{abstract}

Keywords: Production Scheduling, Algorithms, Heuristic Pour. 


\section{Pendahuluan}

Dalam dunia industri saat ini, khususnya Industri manufaktur, perencanaan dan pengendalian produksi memiliki peranan yang sangat penting. Perusahaan menyadari pentingnya ketepatan waktu penyelesaian dalammempertahankan konsumen. Pada penjadwalan sekarang ini job yang telah tiba lebih dahulu akan dilayani lebih dahulu.

Aturan ini tidak mempersoalkan singkat atau lamanya waktu proses. Apabila ada job yang tiba pada saat yang bersamaan maka mereka akan dikerjakan melalui antrian. Aturan ini sering tidak menguntungkan bagi job yang membutuhkan waktu proses yang pendek karena apabila job tersebut berada di belakang antrian akan mengakibatkan waktu menganggur yang lama sebelum diproses pada mesin tersebut. Oleh karena itu dibutuhkan sistem penjadwalan yang baik dan optimal, sehingga menghasilkan selama proses produksi dapat diminimalisir yang pada akhirnya dapat menyelesaikan produk pesanan pelanggan dengan lebih cepat dan produk dapat lebih cepat sampai pada pelanggan (Hendro \& Mulyadi, 2014)

Penjadwalan adalah pengurutan pembuatan atau pengerjaan produk secara menyeluruh yang dikerjakan pada beberapa buah mesin. Tujuan dengan penjadwalan adalah meningkatkan penggunaan sumber daya, mengurangi persediaan barang setengah jadi atau sejumlah pekerjaan yang menunggu dalam antrian, dan mengurangi keterlambatan pada pekerjaan yang mempunyai batas waktu penyelesaian (Baker, 2009). Keputusan yang dibuat dalam penjadwalan meliputi pengurutan pekerjaan (sequencing), waktu mulai dan selesai pekerjaan (timing), urutan operasi untuk suatu pekerjaan (routing). Masalah penjadwalan selalu berkaitan dengan pengurutan produksi (sequencing) yang didefinisikan sebagai penentuan urutanurutan kedatangan dan bermacam-macam pekerjaan yang harus diselesaikan dalam jangka waktu tertentu. Masalah penjadwalan seringkali muncul jika terdapat sekumpulan tugas secara bersamaan, sedangkan peralatan yang dimiliki terbatas. Masukan dari suatu penjadwalan mencakup jenis dan banyaknya part yang akan dioperasi, urutan ketergantungan antar operasi, waktu proses untuk masing- masing operasi, serta fasilitas yang dibutuhkan oleh setiap operasi. Keluaran penjadwalan meliputi dispatch list (daftar urutan-urutan pemrosesan part serta waktu mulai dan selesai dari pemrosesan part) (Ginting, 2009).

Algoritma memegang peranan penting dalam bidang pemrograman. Begitu pentingnya suatu algoritma, sehingga perlu dipahami konsep dasar algoritma. Apalagi untuk seorang programer, tentu diperlukan suatu algoritma sehingga dapat membuat program yang lebih efektif dan efisien. Bagi kebanyakan orang, algoritma sangat membantu dalam memahami konsep logika pemrograman. Algoritma adalah kumpulan instruksi yang dibuat secara jelas untuk menunjukan langkah-langkah penyelesaian suatu masalah. Sebuah algoritma tidak saja harus benar tetapi juga harus mangkus (efisien). Algoritma yang mangkus ialah algoritma yang dapat meminimumkan kebutuhan waktu dan ruang. Dalam bidang komputer, misalnya EDP (Elektronik Data Processing) atau MIS (Management Information System), algoritma sering dimanfaatkan untuk menyelesaikan suatu masalah atau untuk proses pengambilan keputusan. Seorang sistem analisis (analisist system) tentunya menggunakan algoritma untuk merancang suatu sistem. Bagi seorang programer, algoritma digunakan untuk membuat modulmodul program (Wibowo, 2011)

Mengembangkan algoritma heuristik baru di dalam menyelesaikan penjadwalan flowshop (salah satu jenis penjadwalan produksi dimana setiap $n$ job akan melalui setiap $m$ mesin dengan urutan yang seragam) dengan tujuan meminalkan makespan (Total Waktu Penyelesain Job) yaitu berdasarkan pendekatan kombinasi. Hal ini dilakukan dengan cara mengganti setiap job dengan job yang lainnya dalam urutan sampai ditemukan kombinasi urutan yang dapat memenuhi kriteria tujuan. Dalam metode ini diasumsikan bahwa semua job diproses secara terpisah dan independent untuk setiap mesinnya. Berikut adalah notasi yang digunakan (Pour, 2010):

1. $\quad P_{i j}=$ waktu proses dari job $i$ pada mesin $j$.

2. $\quad C_{i j}=$ rentang waktu antara saat job $i$ pada mesin $j$ dimulai $(t=0)$ sampai job itu selesai. 
3. $C_{i}=$ sum of completion time untuk job i pada semua mesin.

4. $\quad F m a x=$ rentang waktu antara saat pekerjaan tersedia atau dapat dimulai sampai pekerjaan itu selesai (makespan).

Sudah banyak penelitian yang dilakukan untuk mencari penyelesaian penjadwalan dengan tujuan meminimumkan waktu penyelesaian job (makespan) diantaranya. Hasil penelitian oleh (Sulaksmi, 2014) menunjukkan algoritma heuristik Pour memberikan performance yang cukup baik dalam menyelesaikan permasalahan penjadwalan flowshop yaitu metode heuristik Pour dapat digunakan sebagai alternatif metode dalam melakukan penjadwalan pengerjaan order di konveksi One Way. Penjadwalan dengan menggunakan metode heuristik Pour menghasilkan makespan lebih cepat sebesar 8,09 jam dari metode FCFS. Penelitian lain yang dilakukan oleh (Siregar, 2009)menunjukkan algoritma heuristik Pour mampu memberikan makespan lebih cepat $5,09 \%$ dibanding aturan FCFS dalam penjadwalan yang dilakukan PT Cakra Compact Alumunium Industries Medan. Selanjutnya Penelitian dari (Widodo, 2014) menghasilkan dengan melakukan perhitungan iterasi satu pada CEGA, diperoleh hasil optimal yang sama dengan hasil pada perhitungan enumerasi. Yaitu didapatkan nilai makespan sebesar 9182 detik pada urutan job 3-2-1-4, dan job 2-3-14. Hal tersebut menunjukkan bahwa terdapat beberapa alternativ untuk mendapatkan jadwal yang optimal.

\section{Metode Penelitian}

Data yang digunakan dalam penelitian ini adalah data dari PT. Asia Penta Garment pada Agustus tahun 2017 yang berkaitan dengan permasalahan yang akan dipecahkan yaitu berupa jumlah mesin yang digunakan dalam operasi, jumlah job yang dikerjakan dan waktu proses setiap job pada setiap mesin yang ada.

Perhitungan waktu standar didasarkan dari data waktu proses produksi, kelonggaran, dan rating faktor yang diperoleh dari hasil pengamatan. Waktu standar adalah waktu yang dibutuhkan mesin yang berkerja secara normal. Rumus untuk menghitung waktu standar yaitu (Morton, 2008):

$$
\begin{aligned}
& W n=\text { wktu pengamatanx } \frac{\text { ratingfactor } \%}{100 \%} \\
& W S=W n \times \frac{100 \%}{100 \%-\% \text { Allowance }}
\end{aligned}
$$

Keteranga :

$\mathrm{Wn}=$ Waktu Normal

Ws = Waktu Standar

waktu $\begin{gathered}\text { Total waktu proses merupakan } \\ \text { yang dibutuhkan untuk }\end{gathered}$ menyelesaikan suatu job berdasarkan jumlah permintaan yang diterima. Waktu ini dipengaruhi juga oleh jumlah mesin yang dimiliki oleh konveksi One Way, kapasitas produksi/mesin dan waktu standar untuk membuat sebuah kaos. Rumus untuk menghitung total waktu proses tiap job pada masing-masing mesin adalah :

\section{Total Waktu Proses}

$=\frac{\text { Waktu Standar } x \text { jumlah permintaan } / \text { Job }}{\text { Jumlah Mesin x Kapasitas Produksi/Mesin }}$

Langkah-langkah pengerjaan:

1. Memilih job secara acak sebagai urutan pertama sementara dalam urutan pengerjaan.

2. Menempatkan job-job lain (selain job yang sudah dipilih sebagai urutan pertama) pada urutan berikutnya.

3. Memilih waktu proses terkecil untuk masing-masing mesin.

4. Melakukan penambahan waktu proses secara increasing time pada $P i$ yang lain, selain $P_{i j}$ paling minimal yang terpilih sebelumnya.

5. Menghitung sum of completion time $\left(C_{i}\right)$ atau jumlah waktu dimana setiap pekerjaan dianggap selesai.

6. Mengurutkan $C_{i}$ dengan aturan increasing job untuk diletakkan pada urutan setelah job yang sudah dipilih untuk urutan pertama sementara.

7. Setelah diperoleh urutan sementara, maka hitunglah Fmax-nya. 
8. Lakukan ulang langkah pada poin a sampai g untuk setiap job yang ada sampai diperoleh Fmax paling minimal, yang akan ditempatkan sebagai urutan pertama dari urutan job.

9. Lakukan ulang langkah pada poin a sampai h semua job berada pada urutan pengerjaan.

\section{Hasil dan Pembahasan}

Produk yang diteliti terdiri dari 5 model jenis pakaian jadi yang berbeda dan melalui 3 tahapan mesin jahit produksi.

Tabel 1.

Kapasitas Mesin

\begin{tabular}{|c|c|c|c|}
\hline Job & M1 & M2 & M3 \\
\hline Job 1 & 2.75 & 1.78 & 0.91 \\
\hline Job 2 & 11.98 & 0.46 & 0.46 \\
\hline Job 3 & 4.46 & 1.84 & 0.19 \\
\hline Job 4 & 7.09 & 0.88 & 0.09 \\
\hline Job 5 & 12.23 & 2.82 & 1.12 \\
\hline \multicolumn{4}{|c}{ Sumber : Data Perusahaan }
\end{tabular}

\section{Keterangan :}

- Jumlah produksi Jaket $=560$ pcs.

- Jumlah produksi Switers $=800$ pcs.

- Jumlah produksi Rok = 300 pcs.

- Jumlah produksi Kemeja $=1.395$ pcs.

- Jumlah produksi Celana $=349$ pcs .

- Jarum $1=\mathrm{M} 1$

- Obras = M2

- Ovredeck = M3

- Job 1 = Jaket

- Job 2 = Switers

- Job $3=$ Rok

- Job 4 = Kemeja

- Job $5=$ Celana

Waktu proses untuk membuat sebuah Produk pada tiap-tiap mesin diperoleh dengan melakukan pengukuran langsung menggunakan stopwatch. Selanjutnya dilakukan perhitungan waktu normal dan waktu standar dengan mempertimbangkan rating faktor dan kelonggaran. Dari hasil perhitungan diperoleh waktu standar masing-masing produk. Metode pada perusahaan saat ini menggunakan yang bertipe make to job, sehingga produksi langsung dilakukan sejumlah permintaan yang ada pada tiap job. Oleh karena itu, input waktu untuk melakukan penjadwalan pengerjaan job pada Bulan Agustus 2017 harus didasarkan dari total waktu proses. Total waktu proses yang dibutuhkan untuk menyelesaikan sebuah job dihitung dengan mempertimbangkan jumlah permintaan pada tiap job, jumlah mesin dan waktu standar untuk membuat sebuah produk.

Tabel 2.

Waktu proses atau Job pada setiap mesin (Jam)

\begin{tabular}{|c|c|c|c|}
\hline Job & Jarum 1 & Obras & $\begin{array}{c}\text { Over- } \\
\text { dek }\end{array}$ \\
\hline $\begin{array}{c}4117 \\
\text { ( Jaket })\end{array}$ & 16 & 11 & 6 \\
\hline $\begin{array}{c}4128 \\
\text { ( Switers) }\end{array}$ & 23 & 7 & 2 \\
\hline $\begin{array}{c}4118 \\
\text { ( Rok })\end{array}$ & 27 & 6 & 1 \\
\hline $\begin{array}{c}4126 \\
\text { (Kemeja) }\end{array}$ & 28 & 3 & 2 \\
\hline $\begin{array}{c}4116 \\
\text { (Celana) }\end{array}$ & 26 & 5 & 3 \\
\hline
\end{tabular}

Sumber : Data Perusahaan

\section{Langkah-langkah penyelesaian :}

Secara umum dalam membangun aplikasi penjadwalan produksi flowshop ini dilakukan melalui tahap-tahap sebagai berikut:

1. Mengambil data sekunder yang diperoleh menjadi data urutan mesin dan waktu pemrosesan. Data tersebut terdiri dari 5 jenis pakaian jadi yang berbeda dan melalui 5 tahapan mesin produksi. Lima jenis pakaian jadi tersebut adalah :

Jaket $=560$ pcs, Switers $=800$ pcs, Rok $=300$ pcs, Kemeja $=395$ pcs, Celana $=349$ pcs. Sedangkan proses pembuatan kertas tersebut melalui 3 tahapan mesin, yaitu mesin jahit 1, Obras dan Overdeck.

2. Membuat penjadwalan produksi mesin dengan algoritma Pour.

3. Membandingkan makespan dan jumlah langkah (performa) dari algoritma Pour.

4. Membuat program penjadwalan produksi mesin menggunakan algoritma Pour.

Penjadwalan jenis flowshop yang ada di perusahan tersebut menggunakan 
aturan First Come First Serve (FCFS). Berdasarkan data, maka jadwal yang digunakan sebagai solusi dengan metode FCFS untuk memproduksi pakaian jadi memiliki urutan job yakni Job 1 - Job 2 Job 3 - Job 4 - Job 5 , dengan perhitungan makespan.

Tabel 3.

Perhitungan makespan dengan metode FCFS

\begin{tabular}{|c|c|c|c|c|c|c|}
\hline \multirow{2}{*}{ Job } & \multicolumn{2}{|c|}{ M1 } & \multicolumn{2}{c|}{ M2 } & \multicolumn{2}{c|}{ M3 } \\
\cline { 2 - 7 } & Mulai & Selesai & Mulai & Selesai & Mulai & Selesai \\
\hline Job 1 & - & 2,75 & 2,75 & 4,53 & 4,53 & 5,44 \\
\hline Job 2 & 2,75 & 14,73 & 14,73 & 5,19 & 15,19 & 15,65 \\
\hline Job 3 & 14,73 & 19,19 & 19,19 & 21,03 & 21,03 & 21,22 \\
\hline Job 4 & 19,19 & 26,28 & 26,28 & 27,16 & 27,16 & 27,25 \\
\hline Job 5 & 26,28 & 38,51 & 38,51 & 41,33 & 41,33 & 42,45 \\
\hline
\end{tabular}

\begin{tabular}{|c|c|c|c|c|c|}
\hline \multirow{2}{*}{$\sum^{m}$} & \multirow{2}{*}{$\begin{array}{l}\text { SELESAI } \\
\text { MULAI }\end{array}$} & $5,44 \quad 15,65$ & 21,22 & 27,25 & 42,45 \\
\hline & & $, 53 \quad 15,19$ & 21,03 & 27,16 & 41,33 \\
\hline \multirow{2}{*}{$\stackrel{N}{\Sigma}$} & SELESAI & $, 53 \quad 15,19$ & 21,03 & 27,16 & 41,33 \\
\hline & MULAI & 7514,73 & 19,19 & 26,28 & 38,51 \\
\hline \multirow{3}{*}{$\stackrel{-1}{\Sigma}$} & SELESAI & 7514,73 & 19,19 & 26,28 & 38,51 \\
\hline & MULAI & 7514,73 & 19,19 & 26,28 & \\
\hline & & & b 1 Jo & Job 3 & ob 5 \\
\hline
\end{tabular}

Gambar 1.

Grafik penjadwalan bulan agustus 2017 dengan aturan FCFS

Penjadwalan dengan menggunakan aturan FCFS sesuai dengan prioritas job yang datang terlebih dahulu menghasilkan urutan pengerjaan job pada Bulan Agustus 2017: job 1-2-3-4-5 dan nilai makespan(Fmax) sebesar 42,45 jam. Artinya dengan jadwal tersebut, industri garment membutuhkan waktu 42.45 jam dalam proses produksinya.

Penjadwalan job pakaian jadi menggunakan algoritma heuristik Pour pada perusahaan dilakukan dengan langkahlangkah sebagai berikut:
1. Memilih job 1 sebagai urutan pertama dalam urutan pengerjaan sehingga waktu proses job pada semua mesin dianggap nol. 2. Menempatkan job-job lain pada urutan berikutnya. Daftar pengurutan job 1 sebagai urutan pertama. 
Tabel 4

Daftar Pengurutan Job 1 sebagai urutan pertama

\begin{tabular}{|c|c|c|c|}
\hline Job & M1 & M2 & M3 \\
\hline Job 1 & - & - & - \\
\hline Job 2 & 11,98 & 0,46 & 0,46 \\
\hline Job 3 & 4,46 & 1,84 & 0,19 \\
\hline Job 4 & 7,09 & 0,88 & 0,09 \\
\hline Job 5 & 12,23 & 2,82 & 1,12 \\
\hline
\end{tabular}

Sumber : Data Perusahaan

3. Memilih waktu proses terkecil untuk masing- masing mesin yaitu: $\mathrm{M} 1=4.46, \mathrm{M} 2$ $=0.46$ dan $\mathrm{M} 3=0.09$.

4. Melakukan penambahan waktu proses (completion time) pada setiap ti,j dengan aturan increasing time yaitu dengan menambahkan waktu proses secara kumulatif dari terkecil sampai terbesar pada setiap ti,j. Sebagai contoh urutan waktu proses di $M 1$ terkecil-terbesar adalah job $1,3,4,2$, dan 5 sehingga waktu proses job 3 di $M 1=4,46$; Job 4 di $M 1=4,46+7,09=$ 11,55; Job 2 di $M 1=11,98+11,55=23,53$, Job 5 di $M 1=12,23+23,53=35,76$.

5. Menghitung sum completion time $(\Sigma C l)$ untuk setiap job.
Tabel 5.

Perhitungan Completion Time dengan Job 1 sebagai Urutan Pertama

\begin{tabular}{|c|c|c|c|c|}
\hline Job & M1 & M2 & M3 & Ci \\
\hline Job 1 & - & - & - & - \\
\hline Job 2 & 23,53 & 0,46 & 0,74 & 24,73 \\
\hline Job 3 & 4,46 & 3,18 & 0,28 & 7,92 \\
\hline Job 4 & 11,55 & 1,34 & 0,09 & 12,98 \\
\hline Job 5 & 35,76 & 4,16 & 1,86 & 41,78 \\
\hline \multicolumn{5}{|c}{ Sumber : Data Perusahaan }
\end{tabular}

6. Mengurutkan $\Sigma \mathrm{Ci}$ dengan aturan increasing time untuk diletakkan pada urutan setelah job 1 yang sudah dipilih sebagai urutan pertama. Dari hasil perhitungan diperoleh urutan sementara dengan job 1 sebagai urutan pertama yaitu: 1-3-4-2-5.

7. Menghitung nilai makespan dengan urutan pengerjaan job 1-3-4-2-5 dan diperoleh makespan sebesar 42,45 jam. (sama dengan hasil penjadwalan dengan metode awal perusahaan)

Tabel 6.

Perhitungan waktu urutan job 1-3-4-2-5

\begin{tabular}{|c|c|c|c|c|c|c|}
\hline \multirow{2}{*}{ Job } & \multicolumn{2}{|c|}{ M1 } & \multicolumn{2}{c|}{ M2 } & \multicolumn{2}{c|}{ M3 } \\
\cline { 2 - 7 } & Mulai & Selesai & Mulai & Selesai & Mulai & Selesai \\
\hline Job 1 & - & 2,75 & 2,75 & 4,53 & 4,53 & 5,44 \\
\hline Job 3 & 2,75 & 7,21 & 7,21 & 9,05 & 9,05 & 9,24 \\
\hline Job 4 & 7,21 & 14,30 & 14,30 & 15,18 & 15,18 & 15,27 \\
\hline Job 2 & 14,30 & 26,28 & 26,28 & 26,74 & 26,74 & 27,20 \\
\hline Job 5 & 26,28 & 38,51 & 38,51 & 41,33 & 41,33 & 42,45 \\
\hline
\end{tabular}

Tabel 7.

Perhitungan waktu urutan job 2-3-4-5-1

\begin{tabular}{|c|c|c|c|c|c|c|}
\hline \multirow{2}{*}{ Job } & \multicolumn{2}{|c|}{ M1 } & \multicolumn{2}{c|}{ M2 } & \multicolumn{2}{c|}{ M3 } \\
\cline { 2 - 7 } & Mulai & Selesai & Mulai & Selesai & Mulai & Selesai \\
\hline Job 2 & - & 11,98 & 11,98 & 12,44 & 12,44 & 12,9 \\
\hline Job 3 & 11,98 & 16,44 & 16,44 & 18,28 & 18,28 & 18,47 \\
\hline Job 4 & 16,44 & 23,53 & 23,53 & 24,41 & 24,41 & 24,5 \\
\hline Job 5 & 23,53 & 35,76 & 35,76 & 38,58 & 38,58 & 39,7 \\
\hline Job 1 & 35,76 & 38,51 & 38,58 & 40,36 & 40,29 & 41,2 \\
\hline
\end{tabular}


Nilai makespan(Fmax)

sebesar 41,20 jam. Artinya dengan

jadwal tersebut, industri garment membutuhkan waktu 41.20 jam dalam proses produksinya.

Tabel 8.

Perhitungan waktu urutan job 3-4-5-1-2

\begin{tabular}{|c|c|c|c|c|c|c|}
\hline \multirow{2}{*}{ Job } & \multicolumn{2}{|c|}{ M1 } & \multicolumn{2}{c|}{ M2 } & \multicolumn{2}{c|}{ M3 } \\
\cline { 2 - 7 } & Mulai & Selesai & Mulai & Selesai & Mulai & Selesai \\
\hline Job 3 & - & 4,46 & 4,46 & 6,3 & 6,3 & 6,49 \\
\hline Job 4 & 4,46 & 11,55 & 11,55 & 12,43 & 12,43 & 12,52 \\
\hline Job 5 & 11,55 & 23,78 & 23,78 & 26,6 & 26,6 & 27,72 \\
\hline Job 1 & 23,78 & 26,53 & 26,6 & 28,38 & 28,31 & 29,22 \\
\hline Job 2 & 26,53 & 38,51 & 38,51 & 38,97 & 38,97 & 39,43 \\
\hline
\end{tabular}

Nilai makespan(Fmax) sebesar 39,43 jam. Artinya dengan jadwal tersebut, industri garment membutuhkan waktu 39.43 jam dalam proses produksinya.

Tabel 9.

Perhitungan waktu urutan job 4-5-1-2-3

\begin{tabular}{|c|c|c|c|c|c|c|}
\hline \multirow{2}{*}{ Job } & \multicolumn{2}{|c|}{ M1 } & \multicolumn{2}{c|}{ M2 } & \multicolumn{2}{c|}{ M3 } \\
\cline { 2 - 7 } & Mulai & Selesai & Mulai & Selesai & Mulai & Selesai \\
\hline Job 4 & - & 7,09 & 7,09 & 7,97 & 7,97 & 8,06 \\
\hline Job 5 & 7,09 & 19,32 & 19,32 & 22,14 & 22,14 & 23,26 \\
\hline Job 1 & 19,32 & 22,07 & 22,07 & 23,85 & 23,85 & 24,76 \\
\hline Job 2 & 22,07 & 34,05 & 34,05 & 34,51 & 34,51 & 34,97 \\
\hline Job 3 & 34,05 & 38,51 & 38,51 & 40,35 & 40,35 & 40,54 \\
\hline
\end{tabular}

Nilai makespan(Fmax)

sebesar 40,54 jam. Artinya dengan jadwal tersebut, industri garment membutuhkan waktu 40,54 jam dalam proses produksinya.

Tabel 10.

Perhitungan waktu urutan job 5-1-2-3-4

\begin{tabular}{|c|c|c|c|c|c|c|}
\hline \multirow{2}{*}{ Job } & \multicolumn{2}{|c|}{ M1 } & \multicolumn{2}{c|}{ M2 } & \multicolumn{2}{c|}{ M3 } \\
\cline { 2 - 7 } & Mulai & Selesai & Mulai & Selesai & Mulai & Selesai \\
\hline Job 5 & 0 & 12,23 & 12,23 & 15,05 & 15,05 & 16,17 \\
\hline Job 1 & 12,23 & 14,98 & 15,05 & 16,83 & 16,83 & 17,74 \\
\hline Job 2 & 14,98 & 26,96 & 26,96 & 27,42 & 27,42 & 27,88 \\
\hline Job 3 & 29,96 & 31,42 & 31,42 & 33,26 & 33,26 & 33,45 \\
\hline Job 4 & 31,42 & 38,51 & 38,51 & 39,39 & 39,39 & 39,48 \\
\hline
\end{tabular}

Nilai makespan(Fmax) sebesar 39,48 jam. Artinya dengan jadwal tersebut, industri garment membutuhkan waktu 39.48 jam dalam proses produksinya. 
Tabel 11

Rekapitulasi Iterasi Heuristik Pour

\begin{tabular}{|c|c|}
\hline Urutan Job & Maskepan \\
\hline $1-2-3-4-5$ & 42,45 \\
\hline $1-3-4-2-5$ & 42,45 \\
\hline $2-3-4-5-1$ & 41,20 \\
\hline $3-4-5-1-2$ & 39,43 \\
\hline $4-5-1-2-3$ & 40,54 \\
\hline $5-1-2-3-4$ & 39,48 \\
\hline
\end{tabular}

Menunjukkan urutan Job sementara 3-4-5-1-2 terpilih karena memberikan makespan yang paling

minimum sebesar 39,43 jam pada bulan Agustus 2017.

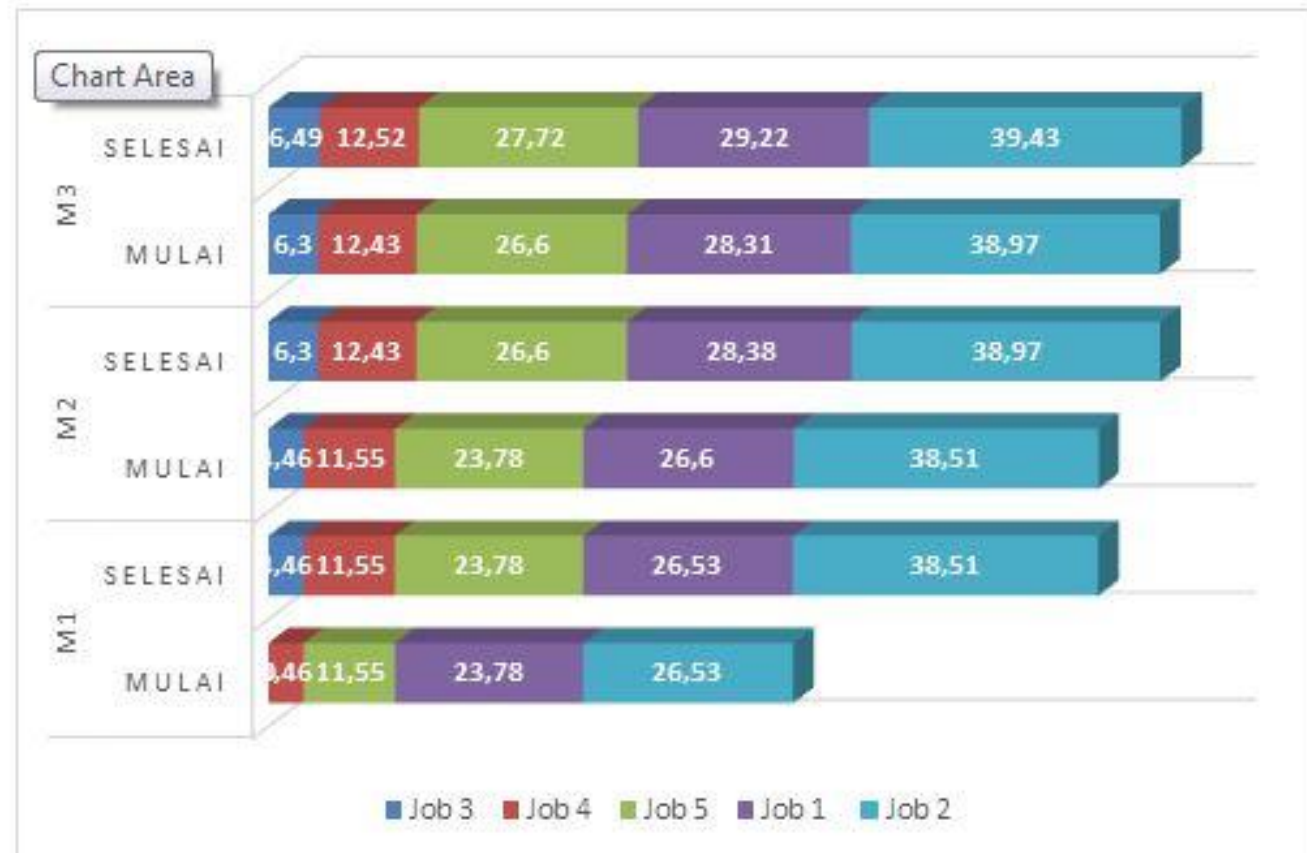

Gambar 2.

Penjadwalan Bulan Agustus 2017 dengan Metode Heuristik Pour

Pada Gambar 2 menunjukkan perhitungan waktu mulai dan selesainya tiap Job pada tiap mesin serta makespan dari hasil penjadwalan dengan algoritma heuristik Pour. Setelah diperoleh penjadwalan dengan metode awal perusahaan dan metode usulan maka langkah selanjutnya adalah melakukan perbandingan untuk melihat apakah algoritma heuristik Pour mampu meminimalkan makespan.

Tabel 12.

Perbandingan Hasil Penjadwalan

\begin{tabular}{|l|c|c|}
\hline & Penjadwalan Awal & Penjadwalan Usulan \\
\hline Urutan & $1-2-3-4-5$ & $3-4-5-1-2$ \\
\hline Hasil Maskepan & 42.45 & 39.43 \\
\hline
\end{tabular}

Algoritma heuristik Pour terbukti memberikan efisiensi waktu karena makespan yang lebih kecil (Afina, 2012) . dalam melakukan penjadwalan produksi diperoleh sehingga job dapat diselesaikan tepat pada waktunya. 
4. Kesimpulan

Metode Heuristik Pour dapat digunakan sebagai alternatif metode dalam melakukan penjadwalan pengerjaan job di perusahaan garment. Penjadwalan dengan menggunakan metode heuristik Pour menghasilkan makespan lebih cepat sebesar 3,02 jam dari metode manual pada Bulan Agustus 2017.

Untuk penelitian selanjutnya diharapkan memperhatikan proses penjadwalan produksi agar tidak terlalu sering terjadi keterlambatan dan dibuatkan program untuk sistem komputerisasi Heuristic pour Algorithm.

\section{Referensi}

Afina, I. (2012). Penjadwalan Produksi Flowshop untuk meminimasi makespan dengan analisis perbandingan Metode Heuristic Pour dan Campbell, Dudek, and Smith (CDS) Pada Lantai Produksi Profil Aluminium di PT. Lindosaluyu Primajaya Cimahi. Prosiding Industrial engeneering Conference On Telecomunication, Universitas Riau.

Baker. (2009). Principle of sequnencing and scheduling. New York: Jhon Wiley \& Sons.

Ginting, R. (2009). Penjadwalan Mesin. Yogyakarta: Graha IImu.

Hendro, \& Mulyadi. (2014). Penjadwalan Produksi Tegel Keramik untuk Meminimasi Makespan dengan menggunakan Metode Agoritma Heuristic Pour dan Algoritma Nawaz and HAM ( NEH ). Jurnal Teknologi dan Manajemen vol. 12 No. 2.

Morton. (2008). Heuristic Scheduling System. New York: Jhon Wiley and Sons.

Pour, H. (2010). A new Heuristic for n-Job m-Machine Flowshop Problem, Production Planning Control. vol.12 no. 7 648-653.

Siregar, A. (2009). Analisa Perbandingan Kinerja antara Algoritma Heuristic Pour dan Algoritma Nawaz, Enscore dan Ham (NEH) dalam menyelesaikan Penjadwalan

Flowshop pada PT. Cakra Compact Aluminium Industries Medan. Teknik Industri.

Sulaksmi. (2014). Penjadwalan Produksi Dengan Algoritma Heuristic Pour ( Studi Kasus : Konveksi One Way Malang ). Jurnal INDD, Vol.15 No. 1 Februari 2014.

Wibowo. (2011). Manajemen Kinerja, Edisi Ketiga. Jakarta: PT. Rajagrafindo Persada.

Widodo. (2014). Pendekatan Algoritma Cross Entropy-Genetic Algorithm untuk menurunkan Makespan pada Penjadwalan FlowSHop. Jurnal Jemis, Universitas Brawijaya, Vol. 2, No.1. 